\title{
INFLUENCE OF PROPERTIES OF THE INTERLAYER SOLDER ON THE STRESS-STRAIN STATE OF BRAZED NODES FROM HEAT-RESISTANT ALLOYS
}

\author{
ВПЛИВ ВЛАСТИВОСТЕЙ ПРОШАРКУ ПРИПОЮ \\ НА НАПРУЖЕНО-ДЕФОРМОВАНИЙ СТАН СПАЯНИХ ВУЗЛІВ \\ 3 ЖАРОМІЦНИХ СПЛАВІВ
}

\author{
Viktor V. Kvasnytskyi ${ }^{1}$ \\ kvas69@ukr.net \\ ORCID: http://orcid.org/0000-0002- \\ 7756-5179

Maksym V. Matviienko²
maksym.matvienko@nuos.edu.ua
ORCID: http://orcid.org/0000-0002-
1020-0415
Yevhen A. Buturlia ${ }^{3}$
welding@nuos.edu.ua
ORCID: http://orcid.org/0000-0003-
2604-5664

В. В. Квасницький, докт. техн. наук, проф.

М. В. Матвіснко, канд. техн. наук, доцент

С. А. Бутурля, аспірант

\author{
${ }^{1}$ National Technical University of Ukraine «Igor Sikorsky Kyiv Polytechnic Institute», Kyiv \\ Національний технічний університет Украйни \\ «Київський політехнічний інститут імені Ігоря Сікорського», м. Київ \\ ${ }^{2}$ Kherson branch of the Admiral Makarov National University of Shipbuilding, Kherson \\ Херсонська філія Національного університету кораблебудування імені адмірала Макарова, м. Херсон \\ ${ }^{3}$ Admiral Makarov National University of Shipbuilding, Nikolayev \\ Національний університет кораблебудування імені адмірала Макарова, м Миколаӥв
}

\begin{abstract}
The stress-strain state (SSS) of heat-resistant alloy assemblies has been studied. Fusion welding of cast heat-resistant alloys does not give positive results. The main method of connection is soldering, but in the joint area is formed interlayer, whose mechanical properties are different from the properties of the parent metal, which leads to the formation of complex SSS, which affects the performance of connections. To study the SSS uses computer modeling by finite element method (ANSYS software package). The SSS at fast and slow cooling of cylindrical samples with interlayer having smaller is investigated yield strength (15\%) and less creep resistance of 15 and $30 \%$ compared to the base metal. Found that a small area of the base metal near the outer surface of the interlayer near the junction and in the layer formed complex SSS. It is shown that the change in the creep resistance of the interlayer in the studied interval has little effect on the nature of the distribution and the magnitude of stresses in the area of bulk SSS. The length of this section is about 5 thicknesses of the interlayer. Plots of radial, axial, tangential and equivalent stresses, as well as principal stresses at different combinations of linear thermal expansion coefficients (LTEC) and speed creep of the base metal and interlayer were obtained. The curves of changes in the stiffness coefficients of the stress state, which is determined by the ratio of principal and equivalent stresses, are given. It is established that the appearance of plastic deformations, both instantaneous and creep in the interlayer has little effect on the stiffness coefficients of the stress state and the degree of hardening or weakening of both the base metal and the interlayer metal. Slow cooling reduces the stress in the interlayer and in a small area of the base metal near the joint near the outer surface of the node due to creep deformation. As the difference between the base metal LTEC and the layer increases, the stress level increases along the entire length of the layer. Therefore, when developing solders, it is necessary to provide them with LTEC close to the LTEC of the base metal. Slow cooling after brazing helps to reduce the stress level due to the deformation of the creep of the interlayer.
\end{abstract}

Key words: computer modeling; plastic deformations; stiffness coefficients of the stress state, high-temperature brazing, heat-resistant alloy 


\begin{abstract}
Анотація. Досліджено напружено-деформований стан (НДС) вузлів з жароміцного сплаву. Зварювання плавленням ливарних жароміцних сплавів не дає позитивних результатів. Основним способом з'єднання є паяння, але в зоні стику формується прошарок, механічні властивості якого відмінні від властивостей основного металу, що призводить до утворення складного НДС, який впливає на працездатність з'єднань. Для вивчення НДС використано комп'ютерне моделювання методом скінченних елементів та програмний комплекс ANSYS.

Досліджено НДС при швидкому й повільному охолодженні циліндричних зразків з прошарками, які мають меншу границю плинності (на 15 \%) та менший опір повзучості на 15 і 30 \%, порівняно з основним металом. Встановлено, що на невеликій ділянці основного металу поблизу зовнішньої поверхні біля стику з прошарком і в самому прошарку формується складний НДС. Показано, що зміна опору повзучості прошарку в досліджуваному інтервалі мало впливає на характер розподілу і величину напружень на ділянці об'ємного НДС. Довжина цієї ділянки складає біля 5 товщин прошарку. Отримано епюри радіальних, осьових, дотичних і еквівалентних напружень, а також головних напружень при різних комбінаціях коефіцієнтів лінійного термічного розширення (КЛТР) і швидкостей повзучості основного металу і прошарків. Наведено криві зміни коефіцієнтів жорсткості напруженого стану, що визначається через співвідношення головних і еквівалентних напружень. Встановлено, що поява пластичних деформацій, як миттєвих, так і повзучості в прошарку мало впливає на коефіцієнт жорсткості напруженого стану і ступінь зміцнення або знеміцнення як основного металу, так і металу прошарку. Повільне охолодження знижує напруження в прошарку і в невеликій ділянці основного металу поблизу стику біля зовнішньої поверхні вузла за рахунок деформацій повзучості. При збільшенні різниці між КЛТР основного металу і прошарку рівень напружень зростає по всій довжині прошарку. Тому при розробці припоїв необхідно забезпечувати їх КЛТР близьким до КЛТР основного металу. Повільне охолодження після паяння сприяє зниженню рівня напружень за рахунок деформацій повзучості прошарку.
\end{abstract}

Ключові слова: комп'ютерне моделювання; пластичні деформації; коефіцієнт жорсткості напруженого стану, високотемпературна пайка, жароміцний сплав

\section{ПОСТАНОВКА ЗАДАЧІ}

Основним завдання сучасного газотурбобудування є Підвищення ефектівності та ресурсу турбін. Підвищення коефіцієнта Корисної Дії двигуна досягається за рахунок Збільшення температури газу перед турбіною. Наприклад, якщо підвищити температуру газу перед турбіною на $230{ }^{\circ} \mathrm{C}$, до $1050{ }^{\circ} \mathrm{C}$ це дозволить вдвічі збільшити потужність і підвищити економічність роботи, не змінюючи габарити ГТД [1]. Підвищення ресурсу роботи ГТД, їх ефективність, а також підвищення температури робочого тіла вимагає використання більш жароміцних матеріалів для тривалої експлуатації в екстремальних умовах роботи.

Основним конструкційним матеріалом в газотурбобудування є жароміцні нікелеві сплави [2]. Металознавство цих сплавів успішно розвивається. Стратегічні напрямки розвитку матеріалів і технологій розглянуті в роботі [3]. Матеріалами нового покоління є інтерметалідні сплави на основі $\mathrm{Ni}_{3} \mathrm{Al}$ [4-6] та ливарні жароміцні нікелеві сплави CM93-BI і СМ96-ВI [7, 8], леговані ренієм і танталом.

Особливістю ливарних жароміцних сплавів $\epsilon$ погана зварюваність плавленням [9]. Тому використовують зварювання в твердому стані (дифузійне зварювання, зварювання тертям) або паяння. Більш універсальним способом є паяння. Розроблено нові способи паяння зокрема контактно-реактивне, дифузійне, композиційними припоями та інші. За кордоном часто використовується термін ТLР-з'єднання (Transint Liquid Phase Bondning - з'єднання через рідку фазу) $[10,11]$. Названі способи з'єднання також мають свої проблеми, що пов'язані з пластичною деформацією для утворення фізичного контакту, активацією поверхонь, що з'єднуються, а також розвитком дифузії і рекристалізації в зоні стику. Для вирішення цих проблем застосовують дифузійне зварювання (ДЗ) з проміжними прошарками, що не розплавляються або розплавляються, при паянні роль проміжного прошарку грає припій, який має фізикомеханічні властивості (ФМВ) відмінні від властивостей основного металу, як до паяння, так і після взаємодії з основним матеріалом. Наявність неоднорідності ФМВ в металі змінює характер напруженодеформованого стану (НДС) і впливає на працездатність з'єднань [12].

Вплив неоднорідності зварних з'єднань на їх НДС і працездатність було встановлено аналітичним методом ще в XX столітті О.А. Бакши [13-15]. Можливості такого методу обмежені. Розвиток комп'ютерної техніки та програмних комплексів дозволяє моделювати НДС з'єднань з урахуванням практично всіх діючих факторів і динаміки процесів $[16,17]$. Тому моделювання НДС при паяні або ТLР-з'єднанні сучасних жароміцних матеріалів $є$ актуальним.

\section{АНАЛІЗ ОСТАННІХ ДОСЛІДЖЕНЬ І ПУБЛІКАЦІЙ}

Початок досліджень особливостей НДС з'єднань різнорідних і однорідних матеріалів 3 проміжними прошарками було покладено академіком НАН України В.І. Махненко, що дозволило розробити технології Д3 і паяння 3 керованими НДС [18], паяння металів 3 неметалами [19], зокрема, завдяки комп'ютерному 
моделюванню НДС в вузлах метал-графіт і металкераміка. Також вплив залишкових напружень на механічні властивості та/або характер руйнування спаяних різнорідних матеріалів вивчалося в роботах [20-22]. Однак робіт, присвячених дослідженню впливу властивостей і характеристик прошарку припою на НДС і працездатність спаяних з'єднань жароміцних нікелевих сплавів, вкрай мало. Наприклад, в роботі [23] досліджено формування НДС при ДЗ i паяння вузлів 3 однорідних металів 3 м'яким прошарком. Вплив товщини проміжного прошарку і його жорсткості на НДС вузла в стані пружності досліджено в роботі [24].

\section{ВІДОКРЕМЛЕННЯ НЕВИРІШЕНИХ РАНІШЕ ЧАСТИН ЗАГАЛЬНОЇ ПРОБЛЕМИ}

У розглянутих роботах досліджено НДС, коли метал і прошарок знаходяться в пружному стані, але при температурах і часу ДЗ і паяння, необхідно враховувати деформації миттєвої пластичності і деформації повзучості, рівняння якої для параметрів режимів ДЗ і паяння в літературі відсутні і їх визначення $\epsilon$ додатковою проблемою. Також проблемою з'єднання різнорідних матеріалів $є$ формування залишкових напружень, а рівень і характер НДС визначається, як поєднанням ФМВ матеріалів, що з'єднуються, так і режимом охолодження.

\section{МЕТА ДОСЛІДЖЕННЯ}

Метою дослідження даної роботи було встановлення закономірності впливу пластичної деформації на напружено-деформований стан спаяних вузлів з жароміцного сплаву нового покоління в умовах охолодження після паяння.

\section{МЕТОДИ, ОБ'ЄКТ ТА ПРЕДМЕТ ДОСЛІДЖЕННЯ}

Об'сктом досліджень був процес формування НДС спаяних вузлів з урахуванням пластичних деформацій.
Предметом досліджень були циліндричні вузли 3 жароміцного сплаву, напруження, пластичні деформації, коефіцієнт жорсткості напруженого стану.

Дослідження впливу поєднання властивостей прошарку і основного металу проводилися на циліндричних моделях (рис.1) 3 висотою і діаметром $\mathrm{h}=\mathrm{d}=20$ мм, при товщині прошарку $\mathrm{s}=0,08$ мм. Досліджувалося НДС вузлів при термічному навантаженні зниженням температури від 1270 до $1100^{\circ} \mathrm{C}$ без урахування і з урахуванням деформацій повзучості.

Властивості основного металу, крім границі плинності, в усіх випадках приймалися однаковими, постійними в інтервалі температур охолодження: модуль пружності $E_{\text {ом }}=0,5 \cdot 10^{5} \mathrm{MПа,} \mathrm{коефіцієнт}$ Пуассона $\mu=0,4$, коефіцієнт зміцнення при пластичній деформації матеріалу $\kappa_{\text {пл }}=0,5 \cdot 102 \mathrm{MПа,}$ коефіцієнт лінійного термічного розширення КЛТР $=21 \cdot 10^{-6} 1 /$ град. При цьому границя плинності (умовна) $\sigma_{\mathrm{p} 0.2}$ прийнятий лінійно зменшуваним від 150 МПа при $1100^{\circ} \mathrm{C}$ до 0 при температурі $1270^{\circ} \mathrm{C}$.

Швидкість повзучості розраховувалася за рівнянням Нортона:

$$
\dot{\varepsilon}_{c r}=C_{1} \cdot \sigma^{C_{2}} \cdot e^{-C_{3} / T},
$$

де $\sigma$ - напруження, Па; $T$ - температура, К.

Коефіцієнти повзучості $\mathrm{C}_{1}, \mathrm{C}_{2}$ i $\mathrm{C}_{3}$ для основного металу отримані шляхом обробки кривих повзучості (жароміцного сплаву на основі $\mathrm{Ni}_{3} \mathrm{Al}$ ): $C_{1}=4,524 \cdot 10^{-29}$, $C_{2}=6,51, C_{3}=92840,8$.

Розглядалися варіанти вузлів 3 прошарками, що мають ФМВ, інші, ніж у основного металу: КЛТР менше в 2 рази $\left(10,5 \cdot 10^{-6} 1 /\right.$ град) і більше в 2 рази (42.10 1/град), ніж у основного металу; з меншою границею плинності (0,85 від границі плинності основного металу), з меншим, ніж у основного металу на 15 і $30 \%$, опором повзучості. Слід зауважити, що чим більше опір повзучості, тим менше ії швидкість.

Швидкість повзучості матеріалу прошарку розраховувалася за тим же рівнянням, що і в основно-

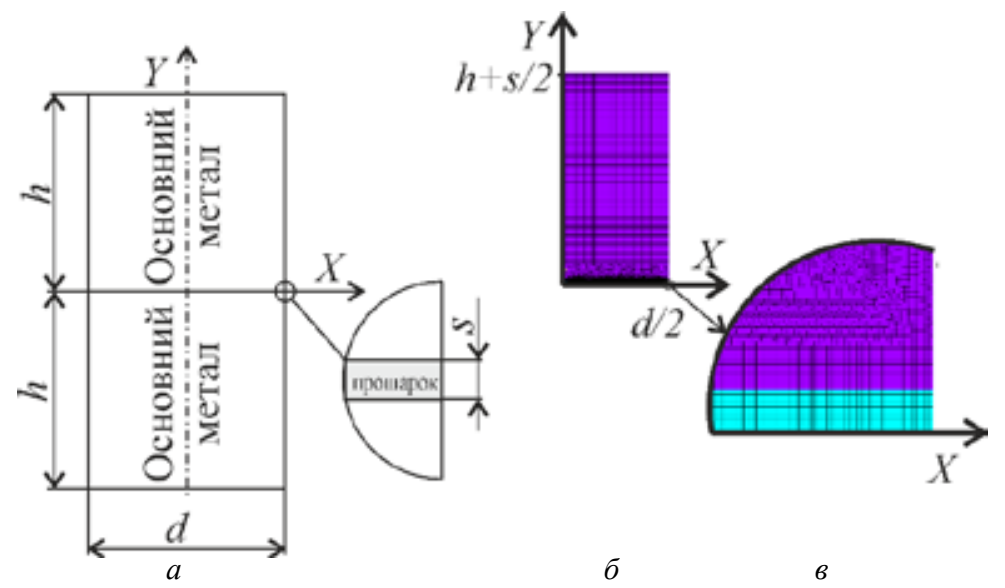

Рис. 1. Загальний вигляд зразка з прошарком $(a)$, перетин скінчено-елементної моделі (б) і зона сполучення прошарку з металом, що з'єднується (в) 
му металі, при цьому коефіцієнти С1 збільшувалися 3 урахуванням зниження опору повзучості і при-

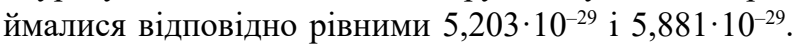
Модуль пружності матеріалу прошарку і коефіцієнт Пуассона у всіх варіантах приймалися однаковими 3 основним металом: $E_{\text {пр }}=0,5 \cdot 10^{5}$ МПа і $\mu=0,4$. Досліджені варіанти вузлів з різними властивостями (КЛТР і швидкість повзучості) прошарку наведені в таблиці 1.

Термічне навантаження проводилося повільним зниженням температури протягом 600 с. Результати порівнювалися 3 варіантами при швидкому охолодженні, коли виникнення пластичних деформацій повзучості не враховувалися (варіанти 1 і 4). При цьому враховувалася можливість пластичного деформування як прошарку, так і основного металу.

Таблиця 1. Варіанти властивостей матеріалу прошарку досліджуваних вузлів

\begin{tabular}{|c|c|c|c|}
\hline Варіант & $\begin{array}{c}\text { КЛТР, } \\
\mathbf{1 0 -} \mathbf{1} /{ }^{\circ} \mathbf{C}\end{array}$ & $\begin{array}{c}\text { Супротив } \\
\text { повзучості по } \\
\text { відношенню к } \\
\text { основному металу }\end{array}$ & $\begin{array}{c}\text { Час } \\
\text { охолодження, } \\
\mathbf{c}\end{array}$ \\
\hline 1 & 10,5 & - & 0 \\
\hline 2 & 10,5 & 0,85 & 600 \\
\hline 3 & 10,5 & 0,7 & 600 \\
\hline 4 & 42 & - & 0 \\
\hline 5 & 42 & 0,85 & 600 \\
\hline 6 & 42 & 0,7 & 600 \\
\hline
\end{tabular}

\section{ОСНОВНИЙ МАТЕРІАЛ}

Аналіз полів всіх складових і еквівалентних напружень показав, що характер їх у всіх варіантах зберігається, дещо змінюється тільки їх величина. Так само, як і при швидкому охолодженні (варіанти 1 і 4), на більшій частині вузла напруження малі, і лише в невеликій зоні, розташованій поблизу прошарку у кромки стику (у зовнішньої поверхні циліндра), і в самому прошарку створюється складний НДС, зумовлений різницею КЛТР металу, що з'єднується, i прошарку. При цьому рівень напружень в варіантах з повільним охолодженням трохи нижче, ніж при швидкому охолодженні.

Повільне охолодження знижує напруження в прошарку і в невеликій зоні основного металу поблизу його кромки за рахунок деформацій повзучості в прошарку. При цьому ступінь опору повзучості прошарку в порівнянні з основним металом в прийнятих межax $(0,85$ або 0,7$)$ практично не грає ролі. Виникаючі деформації повзучості мало впливають на характер поля напружень. Варіанти 1...3 (з прошарком 3 меншим КЛТР) відрізняються від варіантів 4...6 (3 прошарком з більшим КЛТР) тільки рівнем і зворотним знаком напружень.

Дещо інша закономірність зміни полів пластичних деформацій, короткочасних і повзучості. У варі- антах 1, 2 і 3 з меншою різницею КЛТР прошарку і основного металу $\left(10,5 \cdot 10^{-5} 1 /\right.$ град) i, відповідно, 3 меншим рівнем напружень, короткочасні пластичні деформації невеликі, виникають вони тільки у кромки стику. При цьому вони помітно зменшуються в варіантах 2 і 3 в результаті зниження напружень за рахунок повзучості. У варіантах 4, 5 і 6 за рахунок вдвічі більшою різниці КЛТР прошарку і основного металу $\left(21 \cdot 10^{-5} 1 /\right.$ град) i, відповідно, більшого рівня напружень короткочасні пластичні деформації помітно збільшуються і розподілені по всій довжині прошарку. У варіантах з повільним охолодженням (вар. 5 і 6) вони також помітно зменшуються внаслідок повзучості.

Поля пластичних деформацій повзучості показують деяке збільшення їх рівня в вар. 3 і 6 у порівнянні 3 вар. 2 і 5 при зниженні опору повзучості (збільшенні швидкості повзучості) матеріалу прошарку (близько 10\%), і помітне збільшення (до 3-х разів) при збільшенні рівня напружень в вузлі за рахунок більшої різниці КЛТР прошарку і основного металу. Наочне уявлення про характер розподілу і рівні всіх складових і еквівалентних напружень в основному металі і прошарку дають епюри (рис. 2...4).

Аналіз епюр напружень уздовж стику показує, що всі складові і еквівалентні напруження в основному металі практично відсутні на більшій частині стику і тільки в невеликій зоні поблизу зовнішньої поверхні, протяжністю близько 10 товщин прошарку вони зростають. Радіальні (рис. 2,a) до 67 і -102 МПа при швидкому охолодженні (варіанти 1 і 4), до -55 МПа (варіанти 2 і 3) і -73 МПа (варіанти 5 і 6) при повільному. Аналогічно зростають осьові до 68, 46 і 45 МПа в варіантах 1, 2 і 3 і -69, -59 і -58 МПа в варіантах 4, 5 і 6 (рис. 3,a). Окружні змінюються аналогічно радіальним до 54, 40,5 і 40 МПа в варіантах 1, 2 і 3 й -69, -56 і -54 МПа в варіантах 4, 5 і 6 . Дотичні біля самої кромки стику зростають до $-44,-34$ і -33 МПа в варіантах 1, 2 і 3 й 51, 42 і 41,5 МПа в варіантах 4, 5 i 6 (рис. 3, б).

Як видно при порівнянні епюр, знаки складових напружень протилежні в вузлах 3 прошарком 3 меншим (варіанти 1...3) і більшим (варіанти 4...6) КЛТР, ніж у основного металу. При цьому за рахунок повзучості вони незначно знижуються в варіантах 2, 3 і 5, 6 в порівнянні з швидким охолодженням (варіанти 1 і 4).

Відповідно до окремими складовими розподілені і еквівалентні напруження, до кромки стику вони зростають до 76, 60 і 60 МПа в варіантах 1, 2 і 3 й до 87, 76 і 75 МПа в варіантах 4, 5 і 6 (рис. 4,a), тобто, залишаючись значно нижче границі плинності основного металу (150 МПа). Для порівняння, при пружному деформуванні (без урахування пластичних деформацій прошарку) аналогічних вузлів вони становили 100 і 200 МПа в вузлах 3 прошарками 

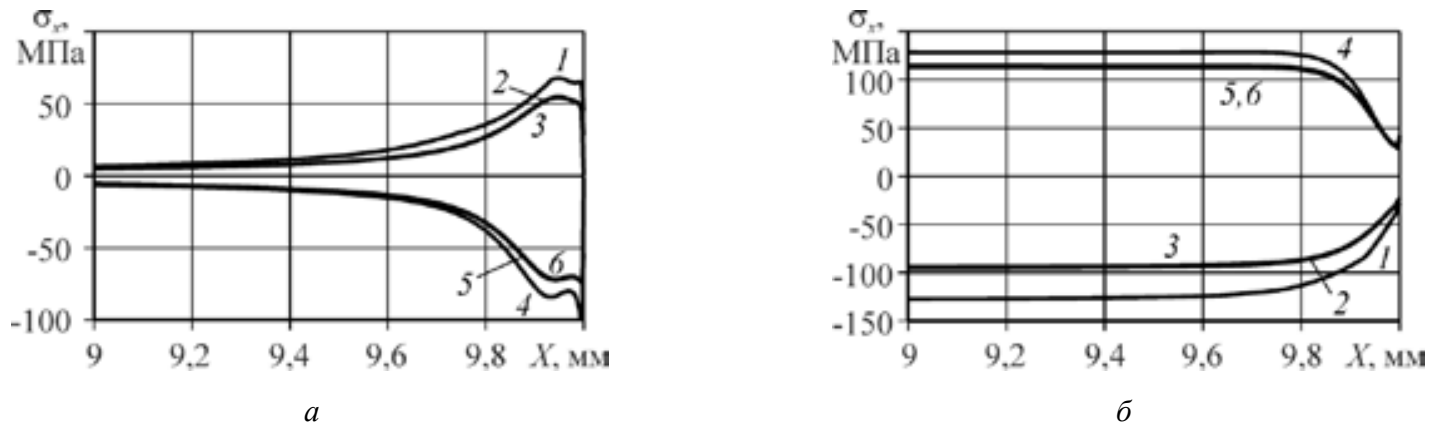

Рис. 2. Епюри радіальних напружень $\sigma_{x}$ по стику в основному металі $(a)$ і прошарку (б) поблизу їі зовнішньої кромки, варіанти 1 ...6.
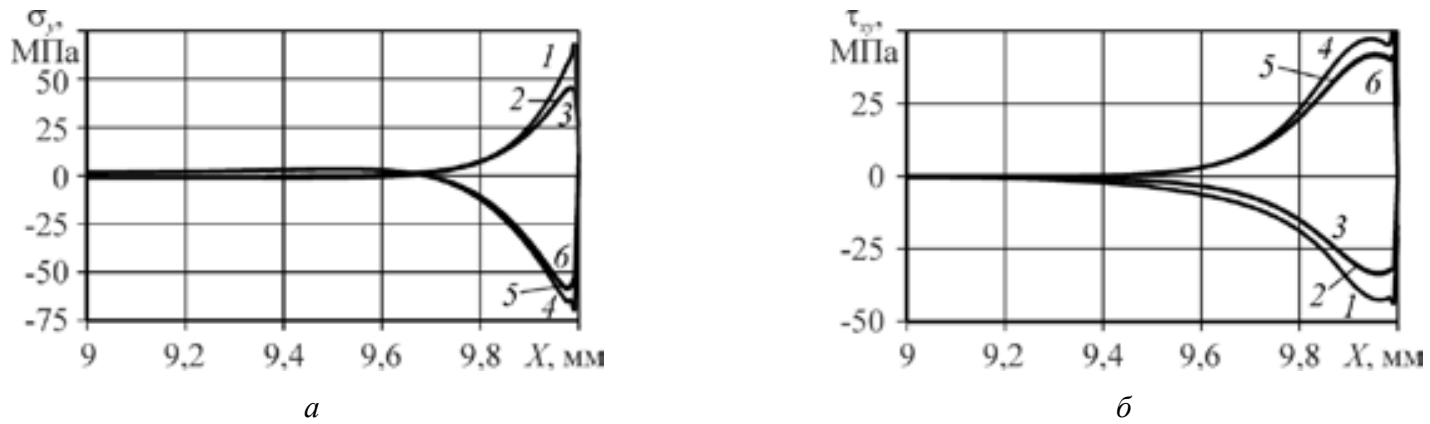

Рис. 3. Епюри осьових $\sigma_{y}(a)$ і дотичних $\tau_{x y}(б)$ напружень по стику основного металу і прошарку поблизу іiї зовнішньої кромки, варіанти 1 ... 6
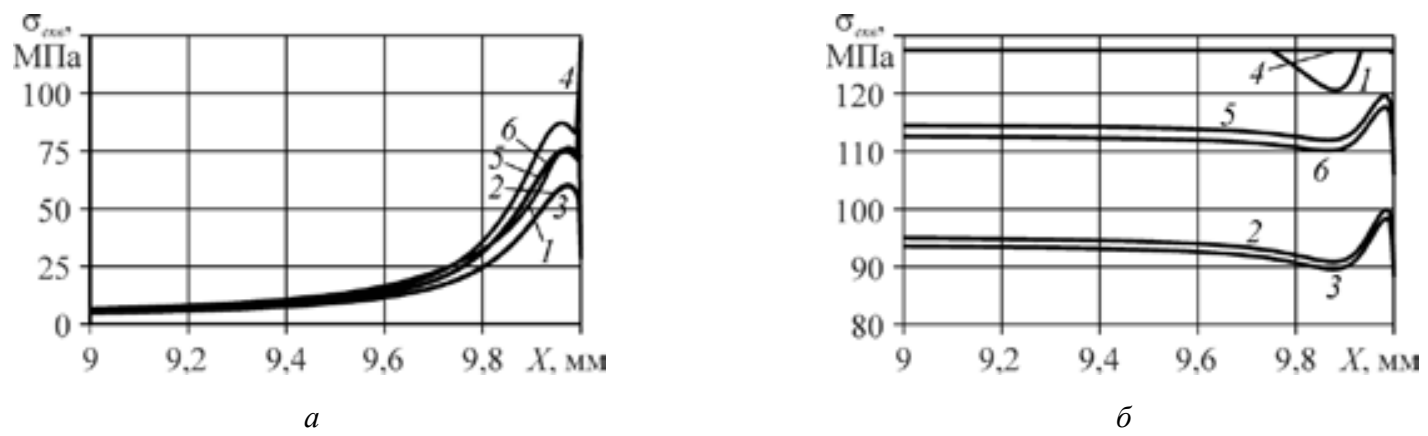

Рис. 4. Епюри еквівалентних напружень $\sigma_{\text {екв }}$ по стику в основному металі $(a)$ і прошарку (б) вузлів, варіанти 1 ...6

з меншим і більшим КЛТР відповідно. Тобто, пластичні деформації матеріалу прошарку знижують еквівалентні напруження в найбільш завантаженій зоні основного металу, розвантажуючи і запобігаючи пластичній деформації в ньому.

У прошарку осьові і дотичні напруження однакові 3 основним металом, вони також відсутні на більшій частині довжини стику (рис. 3, $a$ і б) і тільки поблизу кромки, на відстані близько 5 товщин з'являються і різко зростають, осьові напруження до 68, 46 і 45 МПа в варіантах 1, 2 і 3 й до -69, -59 і -58 МПа в варіантах 4, 5 і 6 , а дотичні до $-44,-34$ і -33 МПа й до 51, 42 і 41,5 МПа відповідно. Радіальні напруження на більшій частині довжини стику в прошарку, на відміну від основного металу, досить великі, розподілені рівномірно на рівні -128, -96 і -94,5 МПа (варіанти 1,
2 і 3) й 128, 115 і 113 МПа (варіанти 4, 5 і 6), тобто близькі до границі плинності (128 МПа) матеріалу прошарку при $1100{ }^{\circ} \mathrm{C}$ (рис. 2,б). Аналогічно розподілені і окружні напруження.

Таким чином, порівняння різних варіантів показує, що деформації повзучості декілька знижують рівень складових напружень, як в основному металі, так і прошарку. При цьому зміна опору повзучості матеріалу прошарку в прийнятих межах (0,8 і 0,75 від основного металу) практично не впливає на ступінь зниження.

Відповідно до складовими розподілені і еквівалентні напруження в прошарку (рис. 4,б). На більшій частині довжини стику вони знижуються за рахунок повзучості матеріалу прошарку і залишаються постійними практично на всій довжині стику: 
у варіантах 1, 2 і 3 на рівні 128, 96 і 94 МПа, а в варіантах 4, 5 і 6 на рівні 128, 115 і 113 МПа.

У відповідності 3 еквівалентними напруженнями розподілені і пластичні деформації в прошарку (рис. 5). Еквівалентні короткочасні пластичні деформації (рис. 5, a) на більшій частині довжини стику постійні, близькі до $0(0,047 \ldots 0,011 \%)$ у варіантах $1 . .3$ і складають $0,404,0,151$ і $0,146 \%$ у варіантах 4...6. Тобто вони істотно збільшуються при збільшенні різниці КЛТР прошарку і основного металу і зменшуються при появі деформацій повзучості і зниженні опору повзучості матеріалу прошарку (рис. 5,a). Поблизу зовнішньої кромки стику вони спочатку дещо зменшуються, а потім знову збільшуються до $0,11,0,028$ і $0,027 \%$ (вар. 1,2 і 3) й 0,57 , 0,234 i 0,226\% (вар. 4, 5 і 6 ).

Аналогічно розподілені і деформації повзучості (рис. 5, б). При швидкому охолодженні (вар. 1 і 4) вони природно відсутні, в інших випадках залишаючись на постійному рівні на більшій частині стику (від 0,114 і 0,284\% в вар. 2 і 5 до 0,118 й $0,294 \%$ в вар. 3 і б), вони поблизу кромки спочатку незначно зменшуються, а потім збільшуються до 0,081 і 0,15\% в вар. 2 і 3 й до 0,343 і 0,358\% в вар. 5 і 6.

Наочне уявлення про зміну рівня деформацій в зоні з'єднання при зміні властивостей прошарку (ії границі плинності, опору повзучості і КЛТР) дає діаграма (рис. 6). Короткочасні (миттєві) пластичні деформації в прошарку за рахунок повзучості зменшуються з $0,047 \%$ у вар. 1 до 0,011 і $0,01 \%$ в вар. 2 і 3 та з 0,404 в вар. 4 до 0,151 і 0,146\% в вар. 5 і 6 відповідно. Деформації повзучості при цьому збільшуються від 0 до вар. 1 і 4 до 0,114 і $0,118 \%$ в вар. 2 і 3 й до 0,284 і 0,294\% в вар. 5 і 6 , помітно перевищуючи рівень короткострокових деформацій.

Обговорення отриманих результатів

Як відомо [25], важливою особливістю об'ємного напруженого стану в порівнянні з лінійним є зміна характеристик міцності (границі плинності) і пластичності (відносного подовження) металу, які визначаються експериментально саме при одноосьово-

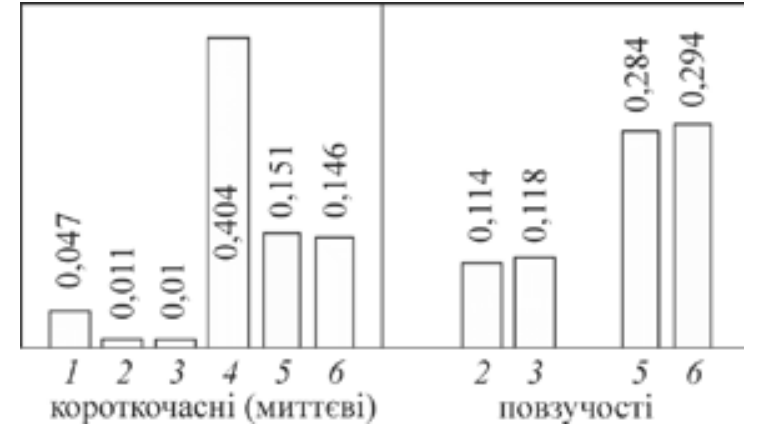

Рис. 6. Пластичні деформації в прошарку (\%) на більшій частині стику, варіанти $1,2,3,4,5$ і 6

му розтягуванні. В умовах об'ємного напруженого стану відбувається зміцнення (підвищення міцності і зниження пластичності) або знеміцнення (зниження міцності і збільшення пластичності) металу. В якості кількісної характеристики цієї зміни використовується коефіцієнт жорсткості напруженого стану $\kappa_{ж}$, рівний відношенню максимальних (по модулю) головних напружень $\left(\sigma_{1}\right.$ або $\left.\sigma_{3}\right)$ (рис. 7) до еквівалентних бекв (рис. 4). Причому максимальними (по модулю) головними напруженнями в основному металі для варіантів 1, 2 і $3 \in \sigma_{1}$, а для варіантів 4, 5 і $6-\sigma_{3}$. У прошарку картина зворотна, для варіантів 1, 2 і 3 максимальними (по модулю) є $\sigma_{3}$, для варіантів 4, 5 і $6-\sigma_{1}$.

Аналіз результатів моделювання НДС при температурному навантаженні показав, що поява пластичних деформацій в прошарку мало впливає на коефіцієнт жорсткості і ступінь зміцнення або знеміцнення, як основного металу, так і матеріалу прошарку (рис. 8).

В основному металі поблизу осі вузла він дорівнює 0,68 поступово збільшуючись по мірі наближення до зовнішньої поверхні до 1,0 на відстані близько 1 мм від неї і до 1,4...1,5 у самій поверхні. У прошарку він залишається рівним 1,0 на більшій частині довжини стику (90\%) і тільки біля самої поверхні спочатку дещо збільшується (до 1,05), а потім
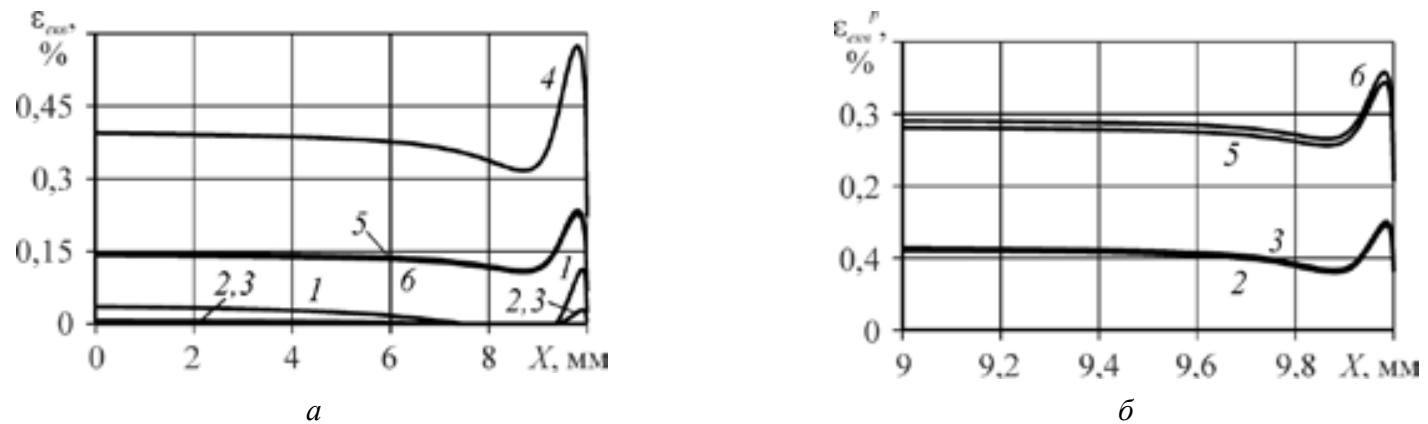

Рис. 5. Епюри еквівалентних короткочасних пластичних деформацій $\varepsilon_{\text {екв }}(a)$ і деформацій повзучості $\varepsilon_{\text {екв }}$ (б) по стику в матеріалі прошарку поблизу іï зовнішньої кромки, варіанти 1 ...6 

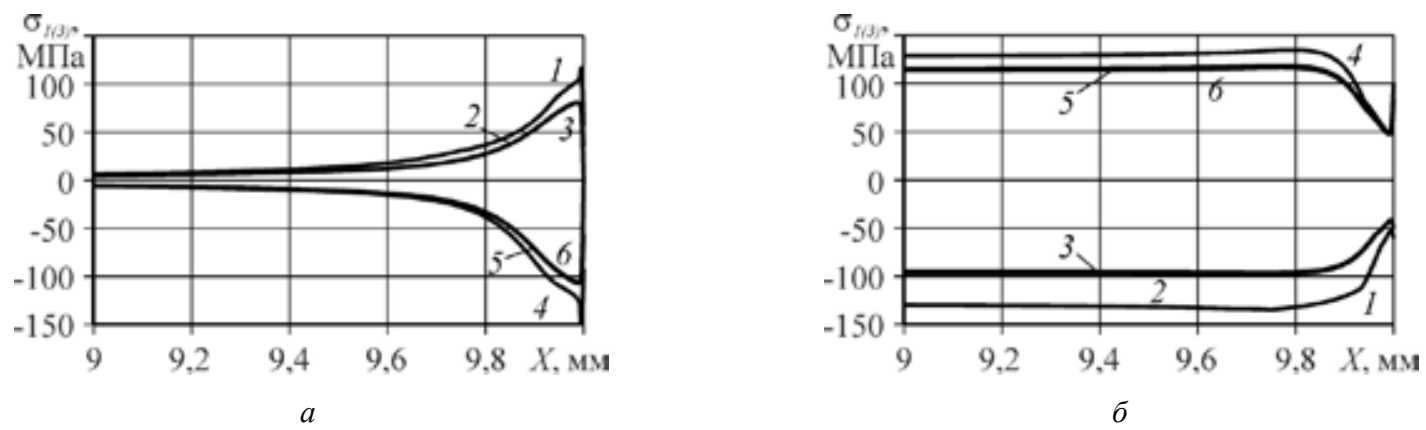

Рис. 7. Епюри максимальних (по модулю) головних напружень $\left(\sigma_{1}\right.$ або $\left.\sigma_{3}\right)$ по стику в основному металі $(a)$ i прошарку $(\sigma)$ вузлів 3 прошарками з різним опором повзучості, варіанти 1 ...6
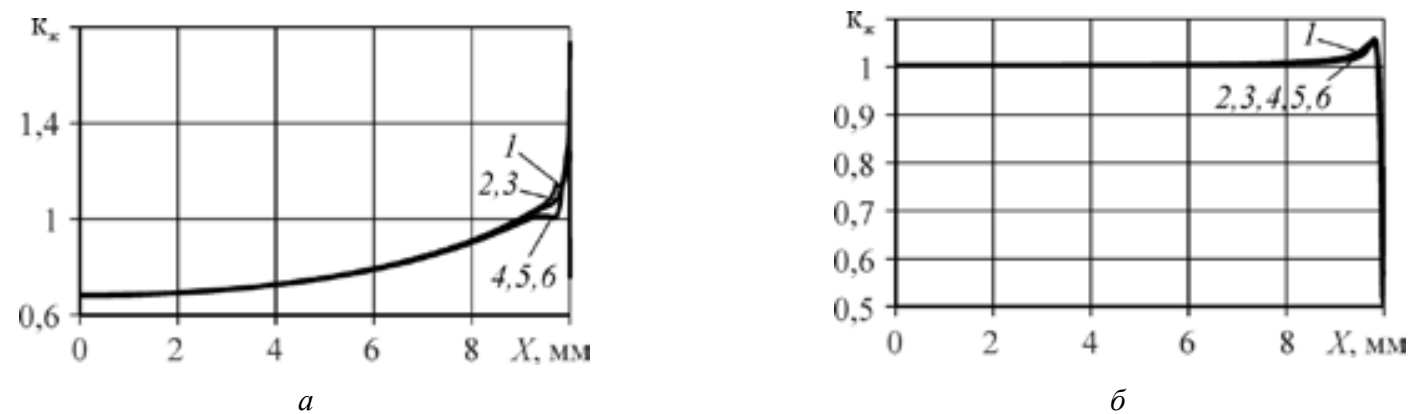

Рис. 8. Зміна коефіцієнтів жорсткості напруженого стану $\kappa_{ж}=\sigma_{1(3)} / \sigma_{\text {екв }}$ по стику в основному металі $(a)$ і прошарку (б), варіанти 1 ...6

різко знижується до $0,6 \ldots 0,8(0,75 \ldots 0,85$ в вар. $1 \ldots .3$ і $0,6 \ldots 0,65$ в вар. 4...6).

3 порівняння епюр 3 аналогічними в пружній задачі [24], видно, що їх характер і рівень, як в основному металі, так і в прошарку, змінюються незначно, в основному на невеликих ділянках поблизу кромки стику. Тут коефіцієнт жорсткості кж в основному металі збільшується (метал зміцнюється) до 1,5, тобто трохи більше, ніж в пружній задачі $(1,35)$. У прошарку він навпаки, знижується (метал знеміцнюється) до 0,5, тобто так само дещо більше, ніж в пружній задачі $(0,6)$. Таким чином, пластичні деформації в прошарку декілька збільшують ефект зміцнення і знеміцнення основного металу і прошарку тільки на зовнішній поверхні вузла.

\section{ВИСНОВКИ}

1. При термічному навантаженні охолодженням вузлів $з$ прошарком в невеликій зоні, розташованій поблизу прошарку у кромки стику (у зовнішньої поверхні циліндра), і в самому прошарку створюється складний НДС, зумовлений різницею КЛТР металу, що з'єднується, і прошарку. При цьому рівень напружень в варіантах 3 повільним охолодженням нижче, ніж при швидкому охолодженні.

2. Повільне охолодження знижує напруження в прошарку і в невеликій зоні основного металу поблизу його кромки за рахунок деформацій повзучості в прошарку. При цьому ступінь опору повзучості прошарку в порівнянні з основним металом в при- йнятих межах $(0,85$ або 0,7$)$ практично не впливають на характер поля напружень.

3. У варіантах з меншою різницею КЛТР прошарку і основного металу $\left(10,5 \cdot 10^{-5} 1 /\right.$ град) і, відповідно, 3 меншим рівнем напружень, короткочасні пластичні деформації невеликі, виникають вони тільки на невеликій ділянці прошарку у кромки стику. При цьому вони помітно зменшуються в результаті зниження напружень за рахунок повзучості.

4. У варіантах з більшою різницею КЛТР прошарку і основного металу $\left(21 \cdot 10^{-5} 1 /\right.$ град) i, відповідно, більшого рівня напружень короткочасні пластичні деформації помітно збільшуються і розподілені по всій довжині прошарку. Тому при розробці припоїв необхідно забезпечувати їх КЛТР близьким до КЛТР основного металу, тобто їх система повинна бути однаковою. У варіантах $з$ повільним охолодженням вони також помітно зменшуються внаслідок повзучості.

5. Деформації повзучості при повільному охолодженні помітно збільшуються зі збільшенням різниці КЛТР прошарку і основного металу, мало змінюючись при зміні опору повзучості прошарку в прийнятих межах.

6. Коефіцієнти жорсткості напруженого стану, а відповідно, і ступінь зміцнення і знеміцнення металу в зоні стику, при повільному охолодженні, як в основному металі, так і в прошарку, змінюються незначно, в основному на невеликих ділянках поблизу кромки стику. 


\section{REFERENCES}

[1] Ivanov M.YA. (2010) Vysokotemperaturnye gazovye turbiny. M.: Topus press. URL: https:// https://www.twirpx.com/ file/1429460/

[2] Kablov, E.N., Ospennikova O.G., Bazyleva O.A. (2011). Materialy dlya vysokonagruzhennyh detalej gazoturbinnyh dvigatelej. Vestnik MGTU im. N.E. Baumana. cer. Mashinostroenie, SP2, 13-19. URL: https://cyberleninka.ru/article/n/ materialy-dlya-vysokoteplonagruzhennyh-detaley-gazoturbinnyh-dvigateley

[3] Kablov, E.N. (2012). Strategicheskie napravleniya razvitiya materialov i tekhnologij ih pererabotki na period do 2030 goda. Aviacionnye materialy i tekhnologii, 8, 7-17. URL: https://viam.ru/public/files/2012/2012-206065.pdf

[4] Myal'nicya, G.P., Maksyuta, I.I., Kvasnic'ka, YU.G., Mihnyan, O.V. (2013). Vibir leguyuchogo kompleksu novogo korozijnostijkogo splavu dlya soplovih lopatok GTD. Metaloznavstvo ta obrobka metaliv, 2, 29-34. URL: http://nbuv.gov.ua/ UJRN/MOM_2013_2_8

[5] Simanovskij, V.M., Maksyuta, I.I., Kvasnickaya, YU.G., Pritulyak, A.S., Mihnyan, E.V. (2010) Teplofizicheskie osobennosti formirovaniya struktury otlivok, poluchennyh metodom napravlennoj kristallizacii. Processy lit'ya. 6. 8-13. URL: http://dspace.nbuv.gov.ua/handle/123456789/49843

[6] Buntushkin V.P., Kablov E.N., Bazyleva O.A., Morozova G.I. (1999) Splavy na osnove alyuminidov nikelya. MiTOM, $1,32-34$.

[7] Maksyuta, I.I., Klyass, O.V., Kvasnickaya, YU.G., Myal'nica, G.F., Mihnyan, E.V. (2014) Tekhnologicheskie osobennosti vysokohromistogo nikelevogo splava kompleksno-legirovannogo reniem i tantalom. Sovremennaya elektrometallurgiya. 1. 41-48. URL: http://dspace.nbuv.gov.ua/handle/123456789/96814

[8] Myal'nica, G.F., Maksyuta, I.I., Kvasnickaya, YU.G., Mihnyan, E.V., Nejma A. V. (2012). Poluchenie orientirovannoj struktury $v$ otlivkah iz zharoprochnogo nikelevogo splava, legirovannogo reniem. Processy lit'ya. $6.54-61$. URL: http://dspace.nbuv.gov.ua/handle/123456789/131102

[9] Kvasnickij V.F. (1986). Svarka i pajka zharoprochnyh splavov v sudostroenii. Leningrad: Sudostroenie URL: https://www. twirpx.com/file/1536160/

[10] Xiong Yue, Fengmei Liu, Hexing Chen, Di Wan \& Hongbo Qin (2018). Effect of bonding Temperature on Microstructure Evolution during TLP Bonding of a $\mathrm{Ni}_{3}$ Al based Superalloy IC10. MATEC web of conferences 206: 03004, DOI: https://doi. org/10.1051/matecconf/201820603004

[11] Jung, D.M., Sharma, A., Mayer, M., Jung, J.P. (2018). A review on recent advances in transient liquid phase (TLP) bonding for thermoelectric power module. Re. Adv. Sci., 53, 147-160. DOI: https://doi.org/10.1515/rams-2018-0011

[12] Mahnenko, V.I. (2006). Resurs ekspluatacii svarnyh soedinenij i uzlov sovremennyh konstrukcij. Kiev: Naukova dumka.

[13] Bakshi O.A., SHron R.Z. (1962) Prochnost' pri staticheskom rastyazhenii svarnyh soedinenij s myagkoj proslojkoj. Svarochnoe proizvodstvo, 5, 6-10.

[14] Bakshi O.A.,Kachanov L.M. (1965) O napryazhennom sostoyanii plastichnoj proslojki pri osesimmetrichnoj deformacii. Izv. AN SSSR. Mekhanika. 2. 134-137.

[15] Bakshi, O.A., SHron, R.Z. (1971) O raschetnoj ocenke prochnosti svarnyh soedinenij s myagkoj proslojkoj. Svarochnoe proizvodstvo. 3, 3-5.

[16] CHigarev, A.V, Kravchuk, A.S, Smalyuk, A.F. (2010). ANSYS v rukah inzhenera: Mekhanika razrusheniya. Moskva: LENAND. URL: https://www.twirpx.com/file/874380/

[17] Morozov, E.M., Mujzemnek, A.YU., SHadskij, A.S. (2010). ANSYS: Spravochnik pol'zovatelya. Moskva: DMK Press. URL: https://www.twirpx.com/file/10492/

[18] Mahnenko, V.I., Kvasnickij, V.V. (2009). Osobennosti formirovaniya napryazhenno-deformirovannogo sostoyaniya soedinenij raznorodnyh materialov, poluchennyh diffuzionnoj svarkoj. Avtomaticheskaya svarka, 8, 11-16. URL: https:// patonpublishinghouse.com/rus/journals/as/2009/08/02

[19] Ermolaev, G.V., Martynenko, V.A., Labartkava, A.V. \& Matvienko M.V. (2017). Effects of the rigid interlayer thicness on the stress-strain of metal-graphite assemblies under thermal loading. Strenght of Materiale, 49 (3), 422-428. DOI: 10.1007/ s11223-017-9882-4

[20] Masayoshi Tateno, Yasushi Fukuzawa, Shigeru Nagasawa, Hiroshi Sakuta, Yoshiyuki Yasutomi, Yo Kojima (1993). Investigation into Reduction of Residual Stress near the Edge of an Interface between Bonded Dissimilar Materials : (Bonding Method That Reduces of Residual Stress). Transactions of the Japan Society of Mechanical Engineers Series A, 59 (558), 428-434 DOI: https://doi.org/10.1299/kikaia.59.428

[21] Zhao Yating, Wang Ying, Yang Zhenwen, Wang Dongpo (2019). Relief of residual stress in $\mathrm{Al}_{2} \mathrm{O}_{3} / \mathrm{Nb}$ joints brazed with $\mathrm{Ag}-\mathrm{Cu}$-Ti/Cu/Ag-Cu-Ti composite interlayer. Archives of Civil and Mechanical Engineering 19 (1). 1-10. DOI: https://doi.org/10.1016/j.acme.2018.08.001

[22] Akbari, M., Buhl, S., Leinenbach, C., Spolenak, R., Wegener, K. (2012) Thermomechanical analysis of residual stresses in brazed diamond metal joints using Raman spectroscopy and finite element simulation. Mechanics of Materials, 52, 69-77. DOI: https://doi.org/10.1016/j.mechmat.2012.04.010

[23] Kvasnickij, V.V., Kvasnikij, V.F., Dong Chunlin, Matvienko, M.V., Ermolaev, G.V. (2018). Napryazhennoe sostoyanie svarnyh i payanyh uzlov iz raznorodnyh materialov s myagkoj proslojkoj pri osevoj nagruzke. Avtomaticheskaya svarka, 4 , 7-13. DOI: http://dx.doi.org/10.15407/as2018.04.01

[24] Kvasnickij, V.V,, Kvasnickij, V.F., Matvienko, M.V., Ermolaev, G.V., Golub D.M. (2019). Komp’yuternoe modelirovanie napryazhenno-deformirovannogo sostoyaniya $v$ usloviyah uprugosti pri pajke i diffuzionnoj svarke $s$ proslojkami $v$ 
zavisimosti ot ih zhestkosti. Visnik Donbas'koï Derzhavnoï mashinobudivnoï akademiï. Zbirnik naukovih prac', 1(45), 43-49. URL: http://nbuv.gov.ua/UJRN/vddma_2019_1_10

[25] Kopel'man, L.A. (2010). Osnovy teorii prochnosti svarnyh konstrukcij: uchebnoe posobie, 2-e izdanie. Peterburg: Lan'. URL: https://nashaucheba.ru/v61169/?cc=1\&view=pdf

\section{СПИСОК ВИКОРИСТАНОЇ ЛІТЕРАТУРИ}

[1] Иванов М.Я. (2010) Высокотемпературные газовые турбины. М.: Топус пресc. URL: https:// https://www.twirpx.com/ file/1429460/

[2] Каблов, Е.Н., Оспенникова О.Г., Базылева О.А. (2011). Материалы для высоконагруженных деталей газотурбинных двигателей. Вестник МГТУ им. Н.Э. Баумана. сер. Машиностроение, SP2, 13-19. URL: https://cyberleninka.ru/ article/n/materialy-dlya-vysokoteplonagruzhennyh-detaley-gazoturbinnyh-dvigateley

[3] Каблов, Е.Н. (2012). Стратегические направления развития материалов и технологий их переработки на период до 2030 года. Авиационные материалы и технологии, 8, 7-17. URL: https://viam.ru/public/files/2012/2012-206065.pdf

[4] Мяльниця, Г.П., Максюта, І.І., Квасницька, Ю.Г., Михнян, О.В. (2013). Вибір легуючого комплексу нового корозійностійкого сплаву для соплових лопаток ГТД. Металознавство та обробка металів, 2, $29-34$. URL: http://nbuv.gov.ua/UJRN/MOM_2013_2_8

[5] Симановский, В.М., Максюта, И.И., Квасницкая, Ю.Г., Притуляк, А.С., Михнян, Е.В. (2010) Теплофизические особенности формирования структуры отливок, полученных методом направленной кристаллизации. Процессы литья. 6. 8-13. URL: http://dspace.nbuv.gov.ua/handle/123456789/49843

[6] Бунтушкин В.П., Каблов Е.Н., Базылева О.А., Морозова Г.И. (1999) Сплавы на основе алюминидов никеля. МиТОМ, $1,32-34$.

[7] Максюта, И.И., Клясс, О.В., Квасницкая, Ю.Г., Мяльница, Г.Ф., Михнян, Е.В. (2014) Технологические особенности высокохромистого никелевого сплава комплексно-легированного рением и танталом. Современная электрометаллургия. 1. 41-48. URL: http://dspace.nbuv.gov.ua/handle/123456789/96814

[8] Мяльница, Г.Ф., Максюта, И.И., Квасницкая, Ю.Г., Михнян, Е.В., Нейма А.В. (2012). Получение ориентированной структуры в отливках из жаропрочного никелевого сплава, легированного рением. Процессы литья. 6. 54-61. URL: http://dspace.nbuv.gov.ua/handle/123456789/131102

[9] Квасницкий В.Ф. (1986). Сварка и пайка жаропрочных сплавов в судостроении. Ленинград: Судостроение. URL: https://www.twirpx.com/file/1536160/

[10] Xiong Yue, Fengmei Liu, Hexing Chen, Di Wan \& Hongbo Qin (2018). Effect of bonding Temperature on Microstructure Evolution during TLP Bonding of a Ni $\mathrm{Al}_{3}$ based Superalloy IC10. MATEC web of conferences 206: 03004. DOI: https://doi.org/10.1051/matecconf/201820603004

[11] Jung, D.M., Sharma, A., Mayer, M., Jung, J.P. (2018). A review on recent advances in transient liquid phase (TLP) bonding for thermoelectric power module. Re. Adv. Sci., 53, 147-160. DOI: https://doi.org/10.1515/rams-2018-0011

[12] Махненко, В.И. (2006). Ресурс эксплуатации сварных соединений и узлов современных конструкций. Киев: Наукова думка.

[13] Бакши О.А., Шрон Р.3. (1962) Прочность при статическом растяжении сварных соединений с мягкой прослойкой. Сварочное производство, 5, 6-10.

[14] Бакши О.А.,Качанов Л.М. (1965) О напряженном состоянии пластичной прослойки при осесимметричной деформации. Изв. АН СССР. Механика, 2, 134-137.

[15] Бакши, О.А., Шрон, Р.3. (1971) О расчетной оценке прочности сварных соединений с мягкой прослойкой. Сварочное производство, 3, 3-5.

[16] Чигарев, А.В., Кравчук, А.С., Смалюк, А.Ф. (2010). ANSYS в руках инженера: Механика разрушения. Москва: ЛЕНАНД. URL: https://www.twirpx.com/file/874380/

[17] Морозов, Е.М., Муйземнек, А.Ю., Шадский, А.С. (2010). ANSYS: Справочник пользователя. Москва: ДМК Пресс. URL: https://www.twirpx.com/file/10492/

[18] Махненко, В.И., Квасницкий, В.В. (2009). Особенности формирования напряженно-деформированного состояния соединений разнородных материалов, полученных диффузионной сваркой. Автоматическая сварка, 8, 11-16. URL: https://patonpublishinghouse.com/rus/journals/as/2009/08/02

[19] Ermolaev G.V., Martynenko V.A., Labartkava A.V. \& Matvienko M.V. (2017). Effects of the rigid interlayer thicness on the stress-strain of metal-graphite assemblies under thermal loading. Strenght of Materiale, 49 (3), $422-428$. DOI: $10.1007 / \mathrm{s} 11223-017-9882-4$

[20] Masayoshi Tateno, Yasushi Fukuzawa, Shigeru Nagasawa, Hiroshi Sakuta, Yoshiyuki Yasutomi, Yo Kojima (1993). Investigation into reduction of residual stress near the edge of an interface between bonded dissimilar materials: (bonding method that reduces of residual stress). Transactions of the Japan Society of Mechanical Engineers Series A, 59 (558), 428-434. DOI: https://doi.org/10.1299/kikaia.59.428

[21] Zhao Yating, Wang Ying, Yang Zhenwen, Wang Dongpo (2019). Relief of residual stress in $\mathrm{Al}_{2} \mathrm{O}_{3} / \mathrm{Nb}_{\text {joints brazed }}$ with $\mathrm{Ag}-\mathrm{Cu}-\mathrm{Ti} / \mathrm{Cu} / \mathrm{Ag}-\mathrm{Cu}$-Ti composite interlayer. Archives of Civil and Mechanical Engineering 19(1). 1-10. DOI: https://doi.org/10.1016/j.acme.2018.08.001 
[22] Akbari, M., Buhl, S., Leinenbach, C., Spolenak, R., Wegener, K. (2012) Thermomechanical analysis of residual stresses in brazed diamond metal joints using Raman spectroscopy and finite element simulation. Mechanics of Materials, 52, 69-77. DOI: https://doi.org/10.1016/j.mechmat.2012.04.010

[23] Квасницкий, В.В., Квасникий, В.Ф., Dong Chunlin, Матвиенко, М.В., Ермолаев, Г.В. (2018). Напряженное состояние сварных и паяных узлов из разнородных материалов с мягкой прослойкой при осевой нагрузке. Автоматическая сварка, 4, 7-13. DOI: http://dx.doi.org/10.15407/as2018.04.01

[24] Квасницкий, В.В,, Квасницкий, В.Ф., Матвиенко, М.В., Ермолаев, Г.В., Голуб Д.М. (2019). Компьютерное моделирование напряженно-деформированного состояния в условиях упругости при пайке и диффузионной сварке с прослойками в зависимости от их жесткости. Вісник Донбаської Державної машинобудівної академії. Збірник наукових праць, 1(45), 43-49. URL: http://nbuv.gov.ua/UJRN/vddma_2019_1_10

[25] Копельман, Л.А. (2010). Основы теории прочности сварных конструкиий: учебное пособие, 2-е издание. Петербург: Лань. URL: https://nashaucheba.ru/v61169/?cc=1\&view=pdf

(c) В. В. Квасницький, М. В. Матвієнко, Є. А. Бутурля Дата надходження статті до редакції: 08.12.2020 Дата затвердження статті до друку: 16.12.2020 